\title{
Assessing the School Heads Leadership in the Towns of Nueva Ecija, Philippines: Inter-Relationship of Supervisory Skills, Interpersonal Skills and Leadership Skills
}

\author{
Aileen Asis Villanueva, Sandi Sanchez Disu, Kim Fe Pauleen Asis Villanueva \\ Nueva Ecija University of Science and Technology, Cabanatuan City, Philippines \\ Email: pax_villanueva@yahoo.com
}

How to cite this paper: Villanueva, A.A., Disu, S.S., Villanueva, K.F.P.A. (2021) Assessing the School Heads Leadership in the Towns of Nueva Ecija, Philippines: InterRelationship of Supervisory Skills, Interpersonal Skills and Leadership Skills. Open Access Library Journal, 8: e8088. https://doi.org/10.4236/oalib.1108088

Received: October 18, 2021

Accepted: November 15, 2021

Published: November 18, 2021

Copyright $\odot 2021$ by author(s) and Open Access Library Inc.

This work is licensed under the Creative Commons Attribution International License (CC BY 4.0).

http://creativecommons.org/licenses/by/4.0/

(c) (i) Open Access

\begin{abstract}
All school is led by a school head who is trained, monitored, and held accountable for organizing and leading an institutionalized school improvement process at the school level, as mandated by Republic Act No. 9155 otherwise identified as the Governance of Basic Education Act of 2001. The study argues that the low performance of schools including their teachers and non-teaching staff emanates from the scarcity of supervisory, interpersonal and leadership skills of school heads. The study adheres to David McClelland's Achievement Power Affiliation Theory which states that an individual's specific needs are acquired over time and are shaped by one's life experiences. By using a total enumeration sampling technique method of research, this study assessed the extent of interpersonal, leadership, and supervisory skills of school heads in the towns of Nueva Ecija, Philippines. A survey questionnaire was used to collect data, which was then analyzed using frequency count, percentage, weighted mean, eta correlation, and t-test. The result of the study revealed that school leaders' interpersonal, leadership, and supervisory skills were regarded as evident by both the school and their teachers. The inter-relationship of Supervisory Skills, Interpersonal Skills and Leadership Skills showed significant associations between the school head's decision making and their managerial skills in planning and organizing thereby concluding that School Heads' leadership was evident.
\end{abstract}

\section{Subject Areas}

Public Policy 


\section{Keywords}

Interpersonal Skills, Leadership Skills, School Heads, Supervisory Skills, School Heads

\section{Introduction and Review of Related Literature and Studies}

Eduardo, J. P., \& Gabriel, A. G. (2017) cited that according to Bohm \& Haley (2005), making the wrong decision can be fatal for the officer or other person [1] [2]. Also, it was cited that Gorry \& Scott Morton (1971) mentioned that decision making is the core of management and aims at selecting the best alternative to achieve an objective [3]. The school heads leadership and performance are interlinked. A slew of worries had descended on school heads. A school head is mandated to assist the school in achieving a high level of performance by maximizing the use of its resources [4]. Given the nature of the research, there is a paucity of literature on this topic. The school head, as a leader and supervisor at the same time, is expected to have the knowledge, skills, and leadership capability to promote student success by managing the school organization, operation, and resources in a way that encourages a secure, efficient, and effective learning environment. The school heads play an important role in supporting the school by communicating a common purpose that distributed leadership is developed within a collaborative school climate. The school heads model leadership using tools and routines; and situational decision making requires principals to make decisions on their own [5] [6] [7]. In the Philippines, Republic Act No. 9155, also known as the Governance of Basic Education Act of 2001, Chapter I Sec. 7, Letter E explicitly mandated each public school or cluster of schools to have a school head who is expected to form a team with the school teachers/learning facilitators to deliver quality educational programs, projects, and services, as well as to a core of non-teaching staff who handles the school's administrative, fiscal, and auxiliary services [8]. This express provision of the law specifically stated how the school head was to carry out his duties. Leadership abilities are expected to be used with the utmost perfection. The act also gives school leaders the authority to direct teachers and students in order to achieve high-quality learning outcomes. Further, Republic Act No. 9155, Chapter 1 Section No. 7, Letter E, Paragraph 3 states that school heads shall have Authority, Responsibility, and Accountability (AuRA) in managing all school affairs in accordance with national educational policies, plans, and standards [9]. Hence, the school's success or failure is determined by the quality of school head the school has.

In these challenging times especially during pandemic when quality education is very much jeopardized, schools need leaders who will exercise the paramount leadership competencies or framework so as to be proficient, effective, competent leader on being structural, human resource, political, and symbolic leaders [10] [11] [12]. 
Luistro, A. (2011) stated in his speech at the Philippine Elementary School Principals' Association (NCR-PSPA) Conference that school leaders must correct, inspire, set the standard, and lead by example [13]. Moreover, former DepEd Sec. Armin Luistro also emphasized that school heads can also serve as a direct link to the sector, allowing more stakeholders to participate in community education and allowing local decision makers, private or non-profit organizations, to participate as collaborators in the school's growth plan. On the other hand, school heads are considered to be the most powerful individuals in schools who can build and develop teacher performances [14]. Further, according to Bago (2008), she defined school heads as the direct individuals who guide, supervise, track, manage, and evaluate the teachers and staff who report to them [15]. School supervision is a complex process with many facets involved. Moreover, all facets of management, both within and outside the classroom, must be taken care of by school heads since they could directly or indirectly influence the delivery of quality education, which is the primary reason for the existence of the school. Among several other functions, a school head is a program leader, a strategic manager, a team leader, an administrator, an evaluator, and sometimes a negotiator. The milieu of a school leader revolves around to many important stakeholders, students, teachers, staff, parents, and community members. The head of the school should have clear and enlightened leadership to realize the school's goals. Good leadership encourages schools to have successful preparation, motivates the organization's citizens to function as a high-performance team, and ensures the school organization's smooth operation in line with its mission and vision [15]. This study knocks around on the premise that supervision is similar to leadership, which has a role and a process. This improves the standard of education, learning, training, and teaching [16]. Many of the issues that arise at the school are immediately addressed by the school head at school level. To get their employees to fully obey, a school head must be skilled. Accordingly, the school heads functions in the day-to-day performance of school activities include encouraging, leading, issuing orders, directing, and leading their subordinates [17].

On the other hand, several studies have found that interpersonal skills are influential at all levels of a job [18]. Interpersonal skills are linked to the development of human relationships and the ability to interact with others [19]. In addition, it is expected that if school heads want to have a successful and productive day with their subordinates, they must consider and inspire them professionally [19]. They need to know how teachers will be influenced by their behavioral actions. Moreover, some researchers have ferret out that in order to achieve performance goals managers should consider both technical and interpersonal skills to grow [20]. The more interpersonally qualified and talented the available school leader is, the better the school will perform. This stems from the fact that leadership based on interpersonal actions encourages cooperation and support, as well as organizational loyalty from the members, heads of the schools must have 
the ability to establish and direct a school's positive development and create and maintain relationships within the school community that influence the overall school environment [20]. The ultimate phenomenon in today's school is the need for school leaders with competent and adequate leadership and managerial skills precisely to advance quality education at all times.

\subsection{Supervisory Skills}

Schools' supervision is a critical mechanism and a combination of practices designed to facilitate teacher and student learning in the school system. It is also a continuous and ongoing personal guidance mechanism centered on regular visits to a school to provide teachers with clear and meaningful suggestions and likewise, supervision is also a constant and continuous process of personal guidance based on frequent visits to a school to provide concrete and constructive advice and encouragement to teachers in order to improve the school's overall performance. For the school head, managerial skill is critical as an instrument for enhancing the performance of teachers in the classroom. Skills are required to perform the managerial duties of the school head [21]. Moreover, experience, interpersonal skills, and technical skills are required as the foundation for supervisory competence [21]. School heads must be knowledgeable about managerial practices in order to improve instructional supervision practices in schools. They must also have the necessary instructional leadership and understand the school's methods and directions in order to achieve the school's desired objectives [22].

\subsection{Interpersonal Skills}

Interpersonal skills are the life skills we use every day, both personally and in groups, to communicate and connect with other people [23]. Further, the commonly few words which are usually used to describe interpersonal skills are social skills, social maturity, people skills, soft skills, social self-efficacy, and social intelligence. Although these words may include interpersonal abilities, they appear to be wider and may therefore apply to other forms of abilities as well. Interpersonal skills are defined as "those abilities required to effectively communicate with another person or group of persons" [24]. Also, interpersonal skills are linked to the foundation of human relationships and the ability to interact with others [19]. Accordingly, if school heads want a successful result at the end of the day, either as individuals or as a collective, they must understand and inspire teachers, school heads need to consider how educators can be influenced by their behavioral actions, school heads will need to consider the types of behavioral activity that can be used within the organization to facilitate a more positive relationship orientation [25].

\subsection{Leadership Skills}

The effectiveness of schools is heavily influenced by the performance of their 
school heads. Good school leaders are those who can bring the vision and mission of the schools they lead to fruition. Accordingly, school leaders refer to school heads because they are qualified to carry out the school's vision, mission, and goals [25]. In addition, as an instructional leader and administrative manager, the school heads has the authority, accountability, and duty to ensure access, promote fairness, and improve the quality of basic education [26]. To thrive in this new setup, the heads of schools need to improve their abilities and management skills for their people. They have to be motivated in schools to be catalysts for change. It is the responsibility of each school administrator to manage the school entrusted to his supervision effectively. To make the school understands its priorities and goals, he should have leadership skills. A strong leader who leads the organization towards achieving the school's mission, which revolves primarily around learning and development, is a major factor in productive schools [27]. Furthermore, leadership is the secret to successful organizational management, if they had the requisite leadership skills, managers would be successful. Moreover, leadership is a vital process and a combination of activities that are concerned with the improvement of teaching and learning environment to promote effective learning in the school system [28].

The inter-relationship between supervisory, interpersonal and leadership skills that school heads must acquire encouraged the researcher to make a study on assessing the school heads leadership in the Towns of Nueva Ecija, Philippines. The study argues that the low performance of schools including their teachers non-teaching staff emanates from the scarcity of supervisory, interpersonal and leadership skills of school heads. Supervisory, interpersonal and leadership skills and its descriptors will be used to assess school heads leadership. The findings of this study can be used to draw a line in the discussion of the insistence for school heads to flourish their interpersonal, leadership, and supervisory skills in order to become efficient, effective, and competent school leaders.

The study, therefore, posed the following problems, to wit:

1) What is the profile of the school heads in terms of:

a) highest educational attainment;

b) present position;

c) years of school management experience;

d) number of teachers supervised?

2) What is the extent of skills demonstrated by the school heads?

3) What is the extent of the school heads' skills as perceived by the teachers?

4) Is there a significant difference in the extent of skills manifested by the school heads as perceived by them and their teachers?

\section{Methodology}

\subsection{Conceptual Framework}

The study adheres to the David McClelland's Achievement Power Affiliation Theory, which states that an individual's specific needs are acquired over time 
and are shaped by one's life experiences. A person's motivation and effectiveness in certain job functions were influenced by a need for achievement, affiliation, and power, ("McClelland's Theory of Needs" n.d.) [29]. Furthermore, the "Oakland County Supervisory Skills Model", developed through Oakland County USA studies, is used in this study, with David Mclelland's Achievement-Power-Affiliation Theory serving as the foundation.

To assess the leadership of school heads, inputs encompasses leadership capability, managerial skills and school performance and it is processed by establishing the inter-relationship of Interpersonal, leadership and supervisory skills base on its corresponding descriptors. Interpersonal skills have three descriptors: building good working relationships, trust, and communication skills. While leadership skill, has five descriptors: identifying and mobilizing resources, initiating action, managing conflict, work standard, and change management. Along with, supervisory skills have four (4) descriptors: decision making, planning and organizing, promoting optimal performance, and professional knowledge/expertise [30]. These are how the study was processed to determine more or less the school heads leadership. How the study would process the same would lead to the output which later on shall serve as another input to analyze leadership capability and managerial skills and school performance. Part of the output of course is the recommendation necessary to improve the School Heads performance, Managerial Strategic Thinking Skills. These could be in the form of formal training, seminar or even attaining mandatory doctoral degree.

Figure 1 shows the relationship between variables. The study used the systems model by examining the leadership capability, managerial skills and school performance as barometer in assessing the leadership of school heads. These are the study's inputs that were analyzed to determine the school heads' leadership. It is processed by determining the extent of Interpersonal skills, Leadership Skills and Supervisory Skills using its respective descriptors. The output of the study will serve as additional input for evaluating school heads' leadership. Part of the output conclusively is recommendations necessary for improving the school heads leadership and managerial skills aimed to improve their school performance.

\subsection{The Research Locale}

The research will take place in the Philippines' province of Nueva Ecija. The archipelago is connected up of 7107 islands. From north to south, it is divided into three major islands: Luzon, Visayas, and Mindanao. Administrative regions and provinces are established on each of the major islands [31]. Nueva Ecija is a typical archipelago province with agriculture serving as the backbone of the economy. The map of the province is shown below (Figure 2).

\subsection{Respondents}

The respondents of the study consist of school heads and teachers from public 
secondary schools in Nueva Ecija, Philippines. There are four (4) congressional districts in Nueva Ecija. The total enumeration sampling technique was used to identify the school heads who served as the respondents. One hundred five (105) teachers were also identified as respondents through the use of the convenience sampling technique.

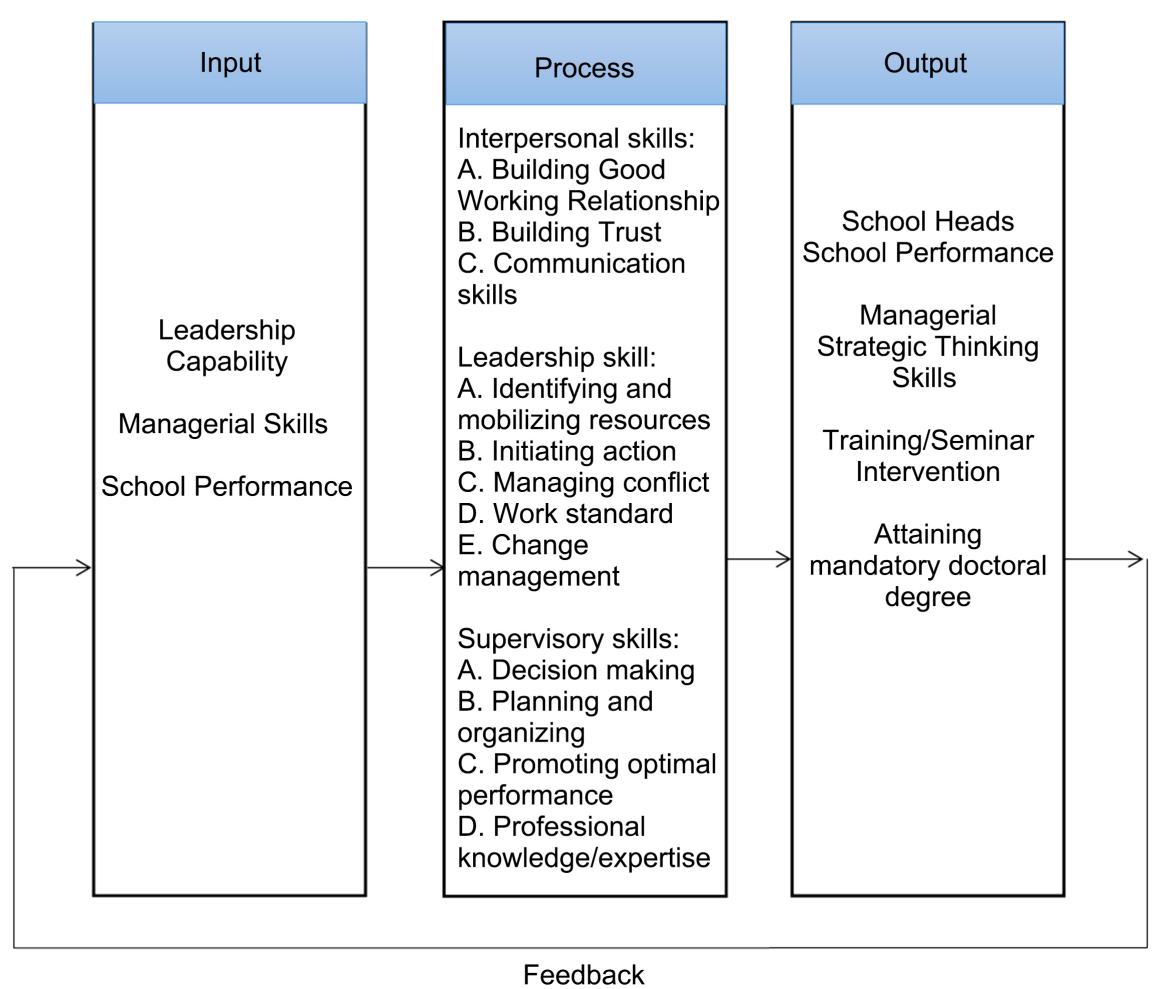

Figure 1. Research paradigm.

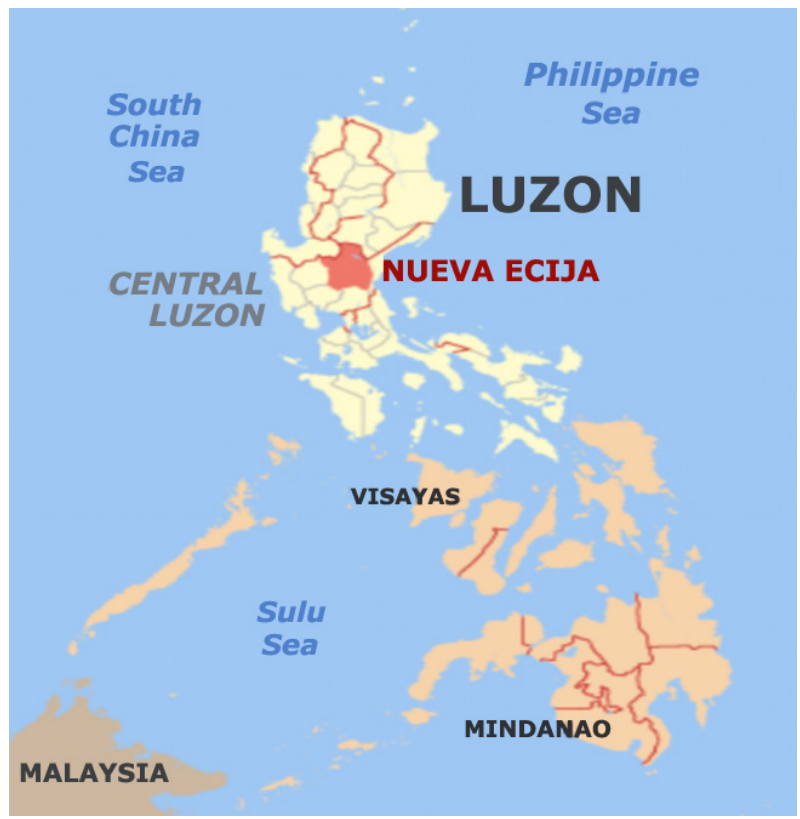

Figure 2. The map of the Province of Nueva Ecija, Philippines. Source: Google Map. 


\subsection{Research Design}

The study used the Descriptive Survey Method aimed at portraying accurately the characteristics of a particular group or situation. This method entails gathering data in order to test hypotheses or answer questions. Kumar (2014) [32] defined this method as systematically describing a situation, problem, phenomenon, service, or program, as well as providing information or describing an attitude toward an issue. It is used to identify and obtain information on leadership skills of school heads in performing their duties and responsibilities consistent with the national educational policies, plans and standards in relation to Republic Act 9155.

\subsection{Data Gathering Procedure}

A survey questionnaire with two (2) parts was used as the research instrument. Part I consists of a self-created questionnaire that determines the respondents' profile in terms of highest educational attainment, current position, years of school management experience, and number of teachers supervised, whereas Part II was adapted from Tampan's (2016) study [33], which is divided into three (3) sections: interpersonal skills, leadership skills, and supervisory skills. Respondents were asked to rate the extent of their interpersonal skills, leadership skills, and supervisory skills on a 5-point Likert scale of 1 to 5, with the following verbal descriptions (Table 1):

\subsection{Data Analysis}

This study used the following statistical tools in interpreting and analyzing the data:

1) Based on their profile, the frequency count and percentage were used to determine the number of school heads.

2) The weighted mean was used to determine the extent to which the indicators of interpersonal, leadership, and supervisory skills are visible among school leaders.

3) Correlation was used to determine the significant relationship between the school heads' profile and their perception of the extent of manifested skills in interpersonal, leadership, and supervisory skills.

Table 1. Response mode on the extent of interpersonal, leadership, and supervisory skills by the school heads.

\begin{tabular}{cc}
\hline Composite Mean & Semantic Deferential \\
\hline $4.01-5.00$ & Very Evident \\
$3.26-4.00$ & Evident \\
$2.51-3.25$ & Moderately Evident \\
$1.76-2.50$ & Evident to a Limited Extent \\
$1.00-1.75$ & Not Evident
\end{tabular}


4) The t-test was used to compare the school heads' demonstrated skills as perceived by them and their teachers and were verified through Pearson Product-Moment Correlation.

\section{Results and Discussions}

\subsection{The Relationship of the Profile of the Respondents as to Their Educational Attainment, Position, Years of Experience, Experience, and Number of Teachers Supervised}

Table 2 shows the highest educational attainment as well as the present status of the school heads. Accordingly, twenty-four percent (24\%) to forty two percent

Table 2. Profile of the respondents as to their highest educational attainment, present position, years of school management, experience, and number of teachers supervised.

\begin{tabular}{|c|c|c|}
\hline Highest Educational Attainment & Frequency & Percentage \\
\hline with Masters' units & 12 & $24 \%$ \\
\hline with Masters' degree & 21 & $42 \%$ \\
\hline with $\mathrm{PhD}$ units & 6 & $12 \%$ \\
\hline with $\mathrm{PhD}$ degree & 11 & $22 \%$ \\
\hline Total & 50 & $100 \%$ \\
\hline \multicolumn{3}{|l|}{ Present Position } \\
\hline Head Teacher with Masters unit/degree & 5 & $10 \%$ \\
\hline School Head I with Masters unit/degree & 14 & $27 \%$ \\
\hline School Head II with Masters/PhD degree & 25 & $50 \%$ \\
\hline School Head III with Masters/PhD degree & 6 & $13 \%$ \\
\hline Total & 50 & $100 \%$ \\
\hline \multicolumn{3}{|l|}{ Years of Experience as School Head } \\
\hline $1-5$ year & 9 & $17 \%$ \\
\hline $6-10$ years & 28 & $56 \%$ \\
\hline $11-15$ years & 12 & $25 \%$ \\
\hline $16-20$ years & 1 & $2 \%$ \\
\hline Total & 50 & $100 \%$ \\
\hline \multicolumn{3}{|l|}{ Number of Teachers and Non-Teaching Staffs } \\
\hline below 10 & 4 & $8 \%$ \\
\hline $10-15$ & 5 & $11 \%$ \\
\hline $16-20$ & 8 & $17 \%$ \\
\hline $21-25$ & 14 & $27 \%$ \\
\hline $26-30$ & 15 & $29 \%$ \\
\hline 51 and above & 4 & $8 \%$ \\
\hline Total & 50 & $100 \%$ \\
\hline
\end{tabular}


(42\%) of the respondents have a master's degree or have acquired master's units and commonly is appointed as Head Teachers and School Head I. Furthermore, twelve percent $(12 \%)$ to twenty two percent $(22 \%)$ of the respondents respectively have is customarily been assigned as School Head II and III. On the other hand, majority of respondents had six (6) to ten (10) years of experience as school head. In addition, twenty eight (28) of the respondents or fifty six percent (56\%) were in charge of managing between 21 and 30 teachers. In the same picture, researcher's conversation with both sets of respondents indicated that everyone thought school heads needed to be competent leaders and managers. Management, which is precisely the function played by school heads, is one of the contributing components for a great education. Because of the complexities of education reform and the fast-changing nature of society, effective principals are critical to the performance and success of schools.

\subsection{The Extent of Interpersonal, Leadership, and Supervisory Skills}

Table 3 shows the level of expertise demonstrated by the school heads. All of their interpersonal skills, leadership skills, and supervisory skills were construed as evident except that of building trust got the highest composite mean of 4.26 labeled as very evident among the interpersonal skills. In their leadership skills,

Table 3. Extent of interpersonal, leadership, and supervisory skills demonstrated by the school heads.

\begin{tabular}{|c|c|c|}
\hline Interpersonal Skills & Composite Mean & Interpretation \\
\hline
\end{tabular}

\begin{tabular}{lcc} 
A. Building good working relationship & 4.00 & Evident \\
B. Building trust & 4.26 & Very Evident \\
C. Communication skills & 3.91 & Evident \\
\hline
\end{tabular}

\begin{tabular}{lll}
\hline Leadership Skills & Composite Mean & Interpretation \\
\hline
\end{tabular}

Descriptor

$\begin{array}{lll}\text { A. Identifying and mobilizing resources } & 3.91 & \text { Evident } \\ \text { B. Initiating action } & 3.80 & \text { Evident } \\ \text { C. Managing conflict } & 4.00 & \text { Evident } \\ \text { D. Work standard } & 4.00 & \text { Evident } \\ \text { E. Change management } & 3.26 & \text { Evident }\end{array}$

\begin{tabular}{|c|c|c|}
\hline Supervisory Skills & & nternretation \\
\hline
\end{tabular}

scriptor
A. Decision making
B. Planning and organizing
C. Promoting optimal performance
D. Professional knowledge/expertise

4.00

Evident

$4.00 \quad$ Evident

3.80

Evident

$4.00 \quad$ Evident 
change management obtained the least composite mean of 3.26 however still labeled as evident while the supervisory skill in promoting optimal performance got the lowest composite mean of 3.80 and was labeled also as evident.

Table 3 also shows that interpersonal relationships are built on trust. Leaders' faith in those they lead enables both the leader and his or her followers to succeed. Leaders' faith in those they lead enables both the leader and his or her followers to succeed [34]. Furthermore, in order to remain effective, school leaders must keep up to date with new developments and trends in all related field areas, in addition to the regular provision of government materials, tools, and resources at all levels for school use [35].

Table 4 shows the extent of skills demonstrated by school principals as perceived by teachers. It should be noted that all of the interpersonal, leadership, and supervisory skills demonstrated by the school heads were deemed evident by the teachers.

\subsection{Significant Difference in Teachers' and School Leaders' Perceptions of Their Skills}

Table 5 presents the demonstrated skills of the school heads as perceived by themselves and by their teachers. Table 5 presents that only Leadership Skills

Table 4. Extent of interpersonal, leadership, and supervisory skills manifested by the school heads as perceived by the teachers.

\begin{tabular}{lcc}
\hline \multicolumn{1}{c}{ Interpersonal Skills } & Composite Mean & Interpretation \\
\hline Descriptors & & \\
A. Building good working relationship & 4.00 & Evident \\
B. Building trust & 4.00 & Evident \\
C. Communication skills & 3.26 & Evident \\
\hline \multicolumn{1}{c}{ Leadership Skills } & Composite Mean & Interpretation \\
\hline Descriptors & & \\
A. Identifying and mobilizing resources & 3.26 & Evident \\
B. Initiating action & 3.80 & Evident \\
C. Managing conflict & 4.00 & Evident \\
D. Work standard & 4.00 & Evident \\
E. Change management & 3.80 & Evident \\
\hline \multicolumn{1}{c}{ Supervisory Skills } & Composite Mean & Interpretation \\
\hline
\end{tabular}

Descriptors
A. Decision making
3.26
Evident
B. Planning and organizing
4.00
Evident
C. Promoting optimal performance
4.00
Evident
D. Professional knowledge/expertise
4.00
Evident 
Table 5. T-test comparing the manifested skills of the school heads as perceived by themselves and their teachers.

\begin{tabular}{cccc}
\hline Correlation & Descriptors & Descriptors & Descriptors \\
& A - C & A - E & A - D \\
\hline Interpersonal Skills & 0.572 & 0.278 & 0.132 \\
& 0.882 & 0.729 & 0.619 \\
\hline Leadership Skills & 0.701 & $0.385^{*}$ & 0.194 \\
\hline Supervisory Skills & 0.853 & 0.768 & 0.671 \\
\hline
\end{tabular}

T-Test: 0.05 level of significance.

and Supervisory Skills have higher Computed Values than their respective Critical Values at 0.05 level of significance; the Ho is rejected. Hence, there is a significant difference in the leadership of school heads only on the two identified areas. However, the Computed Values of Interpersonal Skills, 0.05 level of significance; the Ho is accepted. It implies that School Heads have the same perception as that of their teachers on most of the descriptors of Supervisory Skills, Interpersonal Skills and Leadership Skills.

\section{Conclusions and Recommendations}

\subsection{Conclusion}

The study revealed that supervisory, interpersonal, and leadership skills were paramount for a school head to bolster effective control of resources and duties. From the study, it was evident that school heads had to go beyond being a manager into being a leader and having innate human relationship who would take the school to greater heights. As a result of the study, it is indisputable that a school head must be more than a manager. The school head, who is a manager with immense leadership capabilities and interpersonal skills, is the one who will shine in school management.

Furthermore, the study argued that the low performance of schools including their teachers and non-teaching staff emanates from the scarcity of supervisory, interpersonal and leadership skills of school heads. The following conclusions were achieved:

1) In terms of highest educational attainment and current position, nearly half of the respondents were masters' and $\mathrm{PhD}$ graduates and held School Head II positions. In terms of years of experience in school administration, the majority of respondents have six to ten years of experience. Furthermore, more than half of them supervised 21 - 30 teachers.

2) All of the supervisory, interpersonal, and leadership skills were deemed evident by both the school heads and their teachers. 
3) There were significant associations between the school head's profile in terms of their current position and their manifested supervisory, interpersonal, and leadership skills in initiating action in terms of their current position and in decision making, and in terms of the number of teachers supervised and in terms of plan implementation.

\subsection{Recommendations}

The fact that all of the school heads' interpersonal, leadership, and supervisory skills were described as evident, it is suggested that these skills be honed to a level of very much evident. The lives of school principals are full of challenges; what matters most is how these are dealt with. Thus, it necessitates a paradigm shift away from traditional management practices. Change, collegiality, teamwork, and even efficiency and effectiveness are all required. Change entails school heads acquiring new supervisory, interpersonal and leadership skills in quality development and assurance, as well as the need for more focused and systematic school leadership. Training and seminars to increase the quality of school leadership, as well as development programs to acquire management strategic thinking abilities are highly recommended. In addition, the Department of Education may revisit the qualification standard for School Head II and III applicants requiring a $\mathrm{PhD}$ degree as a minimum prerequisite and for higher plantilla positions.

Further, the Department of Education, may consider the continuing mandatory trainings for school heads' to equip school heads with the imperative leadership and managerial competencies and skills to lead and manage schools and likewise to develop the confidence to go above and beyond the call of duty resulting in the creation of distinctive schools that although driven by policy plume in their own manner.

A broader study is recommended to gain more insights into the relationship between the profile of the school heads and their interpersonal, leadership, and supervisory skills.

\section{Conflicts of Interest}

The authors declare no conflicts of interest.

\section{References}

[1] Eduardo, J.P. and Gabriel, A.G. (2017) Assessing the Leadership Skills of the Chiefs of Police in the Towns of Nueva Ecija, Philippines: A Dichotomy between Managerial Competence and Decision Making Ability. Open Journal of Leadership, 6, 142-159. https://doi.org/10.4236/oj1.2017.64011

[2] Bohm, R.M. and Haley, K.N. (2005) Introduction to Criminal Justice. 4th Edition, McGraw-Hill, New York.

[3] Gorry, G. and Scott Morton, M.S. (1971) A Framework for Management Information System. Sloan Management Review, 13, 55-70.

[4] Smith, W.F. and Andrews R.L. (2013) Instructional Leadership: How Principals Make a Difference. Association for Supervision and Curriculum Development, Alexan- 
dria, 2-5.

[5] Mulford, B. (2003) School Leaders: Challenging Roles and Impact on Teacher and School Effectiveness. OECD Commissioned Paper.

http://www.oecd.org/education/school/37133393.pdf

[6] Hermann, K.R. (2016) The Principal's Role: Distributed Leadership. Theses \& Dissertations, Old Dominion University, Norfolk.

[7] Oracion, C.C. (2017) Teacher Leadership in Public Schools in the Philippines. Unpublished Ed.D. International Thesis. Institute of Education, University of London, London. https://discovery.ucl.ac.uk/id/eprint/10021652/1/Thesis-final.pdf

[8] Republic Act No. 9155. "Governance of Basic Education Act of 2001 Chapter I Sec. 7, Letter E”. https://www.officialgazette.gov.ph

[9] Republic Act No. 9155. "Governance of Basic Education Act of 2001 Chapter 1 Section No. 7, Letter E, Paragraph 3”. https://www.officialgazette.gov.ph

[10] Leithwood, K. (2001) School Leadership and Educational Accountability. International Journal of Educational Leadership, 3, 217-237. https://doi.org/10.1080/13603120110057082

[11] Ali, S. and Rizvi, M. (Eds.) (2007) Quality in Education: Teaching and Leadership in Challenging Times. Vol. 2. Institute for Educational Development, Aga Khan University, Karachi. http://ecommons.aku.edu/books/7

[12] Pont, B., Deborah, N. and Hunter, M. (2008) Improving School Leadership, Volume 1: Policy and Practice. Organization for Economic Co-operation and Development, USA. https://www.oecd.org/education/school/44374889.pdf

[13] Luistro, A. (2011) Speech during the Philippine Elementary School Principals' Association (NCR-PESPA) Conference.

[14] Boris-Schacter, S. and Langer, S. (2006) Balanced Leadership: How Effective Principals Manage Their Work. Teachers College, Columbia University, New York and London.

[15] Bago, A.L. (2008) Supervision of Instruction: The Philippine Perspective. C\&E Publishing, Inc.

[16] De Rijdt, C., Stes, A., van der Vleuten, C. and Dochy, F. (2013) Influencing Variables and Moderators of Transfer of Learning to the Workplace within the Area of Staff Development in Higher Education: A Research Review. Educational Research Review, 8, 48-74. https://doi.org/10.1016/j.edurev.2012.05.007 https://www.ceesvandervleuten.com/application/files/4914/2980/3272/2013_De_Rij dt_Transfer.pdf

[17] Glickman, C.D., Gordon, S.P. and Ross-Gordon, J.M. (2007) Supervision and Instructional Leadership: A Developmental Approach. 7th Edition, Pearson Education, Boston.

[18] Sheikh, S. (2009, April) Alumni Perspectives Survey: Comprehensive Data Report. Graduate Management Admission Council, Reston.

[19] Obakpolo, P. (2015) Improving Interpersonal Relationships in Workplaces. Journal of Research and Method in Education, 5, 115-125. www.iosrjournals.org

[20] McConnell, C.R. (2004) Interpersonal Skills, What They Are, How to Improve Them, and How to Apply Them. Health Care Management, 23, 177-187.

https://doi.org/10.1097/00126450-200404000-00012

https://pubmed.ncbi.nlm.nih.gov/15192999/

[21] Ferris, G.R., Witt, L.A. and Hochwarter, W.A. (2001) Interaction of Social Skill and General Mental Ability on Job Performance and Salary. Journal of Applied Psychol- 
ogy, 86, 1075-1082. https://doi.org/10.1037/0021-9010.86.6.1075

[22] Mislinah, M., Zuraidah, A. and Salwati, S. (2018) The Art of Supervision: Role of Supervisory Skills in Developing Teacher Capacity. Malaysian Online Journal of Educational Management, 6, 37-55.

[23] Rungapadiachy, D.M (1999) Interpersonal Communication and Psychology for Health Care Professionals: Theory and Practice. Butterworth-Heinemann, Oxford. https://trove.nla.gov.au/work/32587657

[24] Wanzare, Z. (2013) Skills and Attributes of Instructional Supervisors: Experience from Kenya. Academic Journals, 8, 2270-2280.

[25] Arman, M., Syamsul, B.T. and Darman, M. (2016) The Effect of School Supervisors Competence and School Principals Competence on Work Motivation and Performance of Junior High School Teachers in Maros Regency, Indonesia. International Journal of Environmental and Science Education, 11, 7309-7317. https://files.eric.ed.gov/fulltext/EJ1115494.pdf

[26] Haris, I., Naway, F.A., Pulukadang, W.T., Takeshita, H. and Ancho, I.V. (2018), School Supervision Practices in the Indonesian Education System; Perspectives and Challenges. https://dergipark.org.tr/tr/download/article-file/496780

[27] Matias, S.V. (2011) The Supervisory Skills of Public Elementary School Principals in the District of Rodriguez I and II, Division of Rizal during the School Year 2010-2011.

[28] Williams, C. (2017). Organization and Management: Concept and Applications. Aviva Publishing House, Inc., Quezon City, 288.

[29] McClelland, D.C. (1985) How Motives, Skills, and Values Determine What People Do. American Psychologist, 40, 812-825.

https://doi.org/10.1037/0003-066X.40.7.812

[30] Maxwel, A. (2017) Supervisory Competency Model. https://silo.tips/download/supervisory-competency-model

[31] Gabriel, A.G. (2017) Indigenous Women and the Law: The Consciousness of Marginalized Women in the Philippines. Asian Journal of Women's Studies, 23, 250-263. https://doi.org/10.1080/12259276.2017.1317705

[32] Kumar, R. (2014) Research Methodology: A Step-by-Step Guide for Beginners. 4th Edition, SAGE, Thousand Oaks.

[33] TAMPAN, I.A.N. (2016) Interpersonal, Leadership and Supervisory Skills of the Administrators of the Cluster a Schools of the Diocese of Butuan, Mindanao, Philippines. SMCC Higher Education Research Journal, 2.

[34] Mineo, D.L. (2014) The Importance of Trust in Leadership. Research Management Review, 20, 1-6. https://files.eric.ed.gov/fulltext/EJ1038828.pdf

[35] Delacruz, M.A. (2017) Effects of Lack on Instructional Materials. https://www.academia.edu/13158439/effects_of_lack_on_instructional_materials 